\title{
Distorsi Pendidikan Karakter Siswa Dalam Pendidikan Jarak Jauh Pada Era Pandemi Covid-19 Di Kabupaten Majene, Indonesia
}

\author{
Mithhar ${ }^{1}$, Andi Agustang ${ }^{2}$ \\ Universitas Negeri Makassar \\ Email: mithharthalaali@gmail.com
}

\begin{abstract}
Abstrak. Penelitian ini bertujuan untuk mengidentifikasi secara mendalam tentang Pelaksanaan dan Distorsi pendidikan karakter siswa dalam Pendidikan Jarak Jauh pada era Pandemi Covid-19 di Kabupaten Majene, Provinsi Sulawesi barat, Indonesia. Data dikumpulkan melalui responden sebanyak 4.380 orang. Responden dipilih secara sengaja pada orang tua siswa atau yang mewakili, mulai dari Sekolah Dasar, Sekolah Menengah Pertama, Sekolah Menengah Atas, dan Sekolah Menengah Kejuruan di Kabupaten Majene. Hasil penelitian menunjukkan bahwa sebanyak 291 sekolah yang tersebar pada 8 (delapan) Kecamatan dengan jumlah 44.949 peserta didik yang aktif melaksanakan Pembelajaran Jarak Jauh (e-learning). Aplikasi yang sering digunakan selama pembelajaran jarak jauh adalah WhatsApp, Ruang Guru, Zoom Meeting, dan Google Calssroom, dan aplikasi-aplikasi lain. Distorsi karakter religius yang mengkuatirkan adalah pada aspek kepedualian pada sesama yang dapat menimbulkan intoleransi, individualistik, dan kurangnya penghargaan kepada orang lain. Distorsi pada karakter nasionalisme muncul karena selama pembelajaran jarak jauh para siswa hampir tidak pernah lagi menghadiri kegiatan bersifat kenegaraan. Distorsi karakter kemandirian siswa ditandai dengan berkembangnya sikap yang mengantungkan diri pada orang tua atau pendampingnya selama melakukan pembelajaran daring. Distorsi pada karakter gotong royong dipicu oleh kurangnya interaksi antar siswa mengakibakan kurangnnya saling pemahaman, tidak saling menghargai, siswa menjadi sangat tertutup dengan teman sebaya. Individualis yang muncul dalam diri siswa mengibatkan kurangnya tolong-menolong antar siswa, kurangnya solidaritas, rendahnya rasa empati yang mengakibatkan sikap kerelawanan menjadi rendah. Distorsi karakter Integritas siswa yaitu kecenderungan siswa untuk tidak jujur pada saat mengikuti tes/ujian. Bentuk kecurangan siswa yaitu dengan memanfaatkan mesin aplikasi pencari untuk menemukan jawaban, serta menggunakan chating di media sosial antar teman.
\end{abstract}

Kata Kunci: Distortion, Character Education, Distance Education, E-Learning

\section{PENDAHULUAN}

Masalah yang terjadi belakangan adalah nilai-nilai karakter sudah mengalami kemerosotan dan berkembangnya perilaku baru yang kini cenderung meluas, yakni: (1) perilaku tidak toleransi antar pemeluk agama; (2) penggunaan bahasa dan katakata yang memburuk; (3) pengaruh peer-group (geng) yang kuat dalam tindak kekerasan; (4) meningkatnya perilaku merusak diri sendiri, seperti penggunaan narkoba, minuman keras; (5) menurunnya integritas; (6) semakin rendahnya rasa hormat kepada orang yang lebih tua; (7) ketidakjujuran semakin membudaya; dan (8) Menebar rasa kebencian di antara sesama. Dan masih banyak lagi misalnya banyak 
terjadi tawuran antar pelajar, pelecehan seksual, korupsi yang merajalela dan sebagainya. Hal ini menunjukkan bahwa karakter positif yang seharusnya dimiliki siswa sebagai fitrahnya semakin sulit ditemui. Oleh sebab itu mutu pendidikan karakter harus ditingkatkan.

Sepanjang sejarahnya, di seluruh dunia ini, pendidikan pada hakikatnya memiliki dua tujuan, yaitu membantu manusia untuk menjadi cerdas dan pintar, dan membantu mereka menjadi manusia yang baik. Menjadikan manusia cerdas dan pintar, boleh jadi mudah melakukannya, tetapi menjadikan manusia agar menjadi orang yang baik dan bijak, tampaknya jauh lebih sulit atau bahkan sangat sulit. Dengan demikian, sangat wajar apabila dikatakan bahwa problem moral merupakan persoalan akut atau penyakit kronis yang mengiringi kehidupan manusia kapan dan di mana pun (Agustang, Mutiara, et al., 2021). Pendidikan dewasa ini lebih banyak berorientasi pada pengembangan pengetahuan dan ketrampilan dengan sedikit menitikberatkan pada karakter yang baik (Sudarsana, 2016).

Pandemi COVID-19 mempengaruhi hampir semua aspek kehidupan, tak terkecuali aspek pendidikan. Pada kondisi pandemi peran dan posisi aspek pendidikan adalah sangat krusial (Wahyono et al., 2020). Karena itu, pemerintah menerapkan pembelajaran secara online dimana siswa belajar di rumah untuk menghindari terpaparnya COVID-19 (Pujiasih, 2020).

Pembelajaran jarak jauh menjadi kebijakan yang diberlakukan oleh negara yang terdampak virus corona termasuk dengan pendidikan di Indonesia (Agustang, A, et al., 2021). Pendidikan dengan kualitas yang bermartabat dan baik dimulai dari terbentuknya karakter mulia peserta didik (Leasa \& Batlolona, 2017). Siswa berkarakter berarti siswa yang berkepribadian, berperilaku, bersifat bertabiat, atau berwatak. Kepribadian merupakan ciri atau karakteristik atau sifat khas dari diri seseorang yang bersumber dari bentukan- bentukan yang diterima dari lingkungan, misalnya keluarga pada masakecil, dan juga bawaan sejak lahir (Nurwahyuni, 2019)

Pendidikan karakter penting untuk menjadi mainstream pokok pendidikan di Indonesia baik di ranah formal, non-formal maupun informal. Faktor yang mempengaruhi pengembangan karakter anak, di antaranya adalah pola asuh di keluarga (parenting style) dan genetic personality siswa (Kamar et al., 2020). Namun, hal yang terabaikan dalam pembelajaran jarak jauh adalah penguatan pendidikan karakter peserta didik. (Ramlafatma et al., 2021).

Pelaksanaan pendidikan jarak jauh (PJJ) pada masa era pandemi Covid-19 menimbulkan berbagai permasalahan. Penguatan pengembangan karakter siswa merupakan hal penting yang terbaikan dalam pelaksanaan PJJ.

Terlepas dari kedudukan, keahlian, atau pengalaman dalam bidang pendidikan, orang tua di dalam keluarga merupakan kewajiban untuk membangun karakter anakanaknya sejak kecil, bahkan sejak dalam kandungan. Kerja sama guru dan orang tua merupakan kunci dari kesuksesan pembelajaran jarak jauh. Tanpa adanya kerjasama yang dilakukan oleh orang tua dan guru, tentu proses pendidikan yang di harapkan tidak akan berjalan dengan baik. 
Adapun rumusan masalah yang menjadi fokus penelitian yaitu:

1. Bagaimana Pelaksanaan pendidikan jarakjauh (PJJ) pada masa era pandemi Covid19 di Kabupaten Majene

2. Bagaimana Distorsi nilai karakter siswa dalam pendidikanjarak jauh di era Pandemi Covid-19 di Kabupaten Majene.

\section{TINJAUAN PUSTAKA}

\section{Pendidikan Jarak jauh Era pandemi Covid-19}

Pembelajaran jarak jauh sebagai model pendidikan jarak jauh bukanlah model pendidikan baru. Awalnya dimulai dengan kursus tertulis, kemudian berkembang menjadi pendidikan tinggi formal dalam bentuk Universitas Terbuka (Marini \& Milawati, 2020).

Pembelajaran jarak jauh, juga disebut "pendidikan jarak jauh", adalah suatu bentuk pembelajaran di mana seorang guru dan siswa berinteraksi dalam jarak, diimplementasikan dengan menggunakan teknologi telekomunikasi. Pembelajaran jarak jauh menyediakan interaktivitas dari proses pembelajaran. Metode pembelajaran ini dibangun dengan menggunakan teknologi yang memungkinkan interaksi siswaguru, meskipun mereka terjadi di lingkungan fisik dan garis waktu yang berbeda.(Gardanova et al., 2020). Pendidikan jarak jauh adalah seperangkat metode pengajaran dimana kegiatan pengajaran dilakukan secara terpisah Kegiatan Pembelajaran. Pemisahan kedua aktivitas tersebut dapat berupa jarak fisik (Marini \& Milawati, 2020), PJJ adalah suatu sistem pendidikan yang memiliki karakteristik terbuka, belajar mandiri, dan belajar tuntas dengan memanfaatkan Teknologi, Informasi dan Komunikasi (TIK) dan/atau menggunakan teknologi lainnya, dan/atau berbentuk pembelajaran terpadu perguruan tinggi (Sari et al., 2020)

Kondisi saat ini pembelajaran diperkaya dengan internet dan blended, teknologi bukan segala-galanya dan belum tentu cocok dengan semua siswa. Pedagogy lebih utama dari pada teknologi(Jusuf et al., 2020)

\section{Membangun Karakter Siswa}

Pembentukan karakter sangat penting kita lakukan pada saat anak kita masih usia dini, dan orang tua harus mempunyai visi untuk pembentukan ini. Karakter adalah watak, tabiat, akhlak, atau kepribadian seseorang yangterbentuk dari hasil internalisasi berbagai kebajikan (virtues) yang diyakini dan digunakan sebagai landasan untuk cara pandang, berpikir, bersikap, dan bertindak. Pendidikan karakter pada dasarnya adalah pengembangan nilai-nilai yang berasal dari pandangan hidup atau ideologi bangsa, agama, budaya, dan nilai-nilai yang berlaku dalam masyarakat (Ashmarita;Hasniah, 2016).

Gerakan PPK (Penguatan Pendidikan Karakter), yang dicanangkan oleh Kementerian Pendidikan dan Kebudayaan Republik Indonesia pada tahun 2017, mengidentifkasi lima nilai utama karakter yang saling berkaitan dalam membentuk jejaring nilai yang perlu dikembangkan sebagai prioritas, yaitu: nilai religius, nasionalis, 
mandiri, gotong-royong, dan integritas (Kemendiknas RI, 2010a dan 2010b; Asmani, 2011; dan Komalasari \& Saripudin, 2017)

Nilai karakter religius ini meliputi tiga dimensi relasi sekaligus, yaitu: hubungan individu dengan Tuhan, individu dengan sesama, dan individu dengan alam semesta atau lingkungan (Asmani, 2011; dan Ningsih, 2015).

Kedua, nilai karakter nasionalis merupakan cara berpikir, bersikap, dan berbuat yang menunjukan kesetiaan, kepedulian, dan penghargaan yang tinggi terhadap bahasa, lingkungan fisik, sosial, budaya, ekonomi, dan politik bangsa, menempatkan kepentingan bangsa dan negara di atas kepentingan diri dan kelompoknya. Sub-nilai nasionalis, antara lain, apresiasi budaya bangsa sendiri, menjaga kekayaan budaya bangsa, rela berkorban, unggul dan berprestasi, cinta tanah air, menjaga lingkungan, taat hukum, disiplin, serta menghormati keragaman budaya, suku, dan agama (Muslich, 2011; Rahardjo, 2013; dan Priyambodo, 2017).

Ketiga, nilai karakter mandiri merupakan sikap dan perilaku tidak bergantung pada orang lain dan mempergunakan segala tenaga, pikiran, dan waktu untuk merealisasikan harapan, mimpi, dan cita-cita. Sub-nilai mandiri, antara lain, etos kerja atau kerja keras, tangguh dan tahan banting, daya juang, profesional, kreatif, keberanian, dan menjadi pembelajar sepanjang hayat (Koesoema, 2007; dan Yusuf, 2017).

Keempat, nilai karakter gotong-royong mencerminkan tindakan menghargai semangat kerja sama dan bahu membahu menyelesaikan persoalan bersama, menjalin komunikasi dan persabatan, serta memberi bantuan atau pertolongan pada orangorang yang membutuhkan. Sub-nilai gotongroyong, antara lain, menghargai, kerja sama, inklusif, komitmen atas keputusan bersama, musyawarah dan mufakat, tolongmenolong, solidaritas, empati, anti diskriminasi, anti kekerasan, dan sikap kerelawanan (Zainal, 2011; dan Wahono \& Priyanto, 2017).

Kelima, nilai karakter integritas merupakan nilai yang mendasari perilaku yang didasarkan pada upaya menjadikan dirinya sebagai orang yang selalu dapat dipercaya dalam perkataan, tindakan, dan pekerjaan, serta memiliki komitmen dan kesetiaan pada nilai-nilai kemanusiaan dan moral atau integritas moral. Karakter integritas meliputi sikap tanggung jawab sebagai warga negara, aktif terlibat dalam kehidupan sosial, serta konsistensi dalam tindakan dan perkataan yang berdasarkan kebenaran. Sub-nilai integritas, antara lain, kejujuran, cinta pada kebenaran, setia, komitmen moral, anti korupsi, keadilan, tanggung jawab, keteladanan, dan menghargai martabat individu (Asmani, 2011; Samani \& Hariyanto, 2011; Barnawi \& Arifin, 2012; dan Yusuf, 2017).

\section{METODE PENELITIAN}

\section{Pendekatan dan Jenis Penelitian}

Pendekatan penelitian yang digunakan adalah pendekatan kualitatif dengan penelitian deskriptif. Agar penelitian ini penelaahannya lebih memberikan deskripsi yang lebih jelas dan mendalam tentang berbagai makna yang ada dibelakang fakta, 
maka digunakan Metode Fenomenologi dengan perspektif interpretative (Agustang, 2011). Sedang fenomenanya adalah pendidikan jarak jauh dan distorsi nilai karakter siswa pada era pandemi Covid-19 di Kabupaten Majene.

Data yang dibutuhkan dalam penelitian ini dibagi dalam dua kategori, yakni data primer dan data sekunder, maka data-data atau keterangan-keterangan yang bersifat primer dikumpulkan melalui kuesioner dan wawancara dengan informan (Andi Agustang, 2015).

Kuesioner untuk responden dibagi menjadi empat sasaran, yaitu kuesioner untuk orang tua atau yang mewakili bagi Sekolah Dasar 2.865 SD, 930 SMP, 330 SMA, dan 255 SMK. Sehingga total jumlah responden 4.380. Informan digunakan untuk memberi penguata kepada hasil kuesioner yang dipilih sesuai kebutuhan data. Sedang data-data atau keterangan-keterangan yang bersifat sekunder, dikumpulkan dari Instansi yang ada hubungannya dengan penelitian ini (Dinas Pendidikan, Kantor Desa, dan Kantor Kecamatan).

\section{Definisi Operasional}

Pembangunan Karakter Siswa mengacu pada lima nilai utama karakter yang saling berkaitan dalam membentuk jejaring nilai sebagai prioritas, yaitu: 1. nilai religius, 2. nasionalis, 3. mandiri, 4. gotong-royong, dan 5. integritas

Pembelajaran Jarak Jauh, merupakan bentuk pembelajaran di mana seorang guru dan siswa berinteraksi dalam jarak, diimplementasikan dengan menggunakan teknologi telekomunikasi. Pembelajaran jarak jauh menyediakan interaktivitas dari proses pembelajaran. Metode pembelajaran ini dibangun dengan menggunakan teknologi yang memungkinkan interaksi siswa-guru, meskipun mereka terjadi di lingkungan fisik dan garis waktu yang berbeda.

\section{HASIL DAN PEMBAHASAN}

\section{Pelaksanaan Pembelajaran Jarak Jauh di Kabupaten Majene}

Pembatasan Sosial Berskala Besar di Kabupaten Majene, mewajibkan melaksanakan kegiatan kerja dan pembelajaran secara jarak jauh dengan menggunakan teknologi internet bagi guru dan siswa peserta pembelajaran. Proses pembelajaran yang biasanya dilaksanakan di sekolah dengan tatap muka langsung dengan bapak atau ibu guru dan teman-teman tidak dapat dilakukan pada masa pandemi Covid-19. Para siswa diharuskan belajar dari rumah, untuk itu guru juga diharuskan menyiapkan perangkat pembelajaran yang memungkinkan siswa untuk belajar dari rumah. Kondisi ini membuat guru harus mengubah strategi belajar mengajarnya. Penggunaan metode pengajaran yang tepat maupun perilaku dan sikap guru dalam mengelola proses belajar mengajar sangat dibutuhkan dalam pembelajaran selama program belajar dari rumah. Semua ini dilakukan untuk memberikan akses pembelajaran yang tidak terbatas ruang dan waktu kepada peserta didik selama diberlakukannya masa darurat Covid-19.

Jumlah sekolah Di Kabupaten Majene, mulai dari Sekolah Dasar, Sekolah Menengah Pertama, Sekolah Menengah Atas, dan Sekolah Menengah Kejuruan 
sebanyak 292 sekolah yang tersebar pada 8 (delapan) Kecamatan (Tabel 1). Jumlah itu dihuni oleh 44.949 peserta didik yang aktif melaksanakan Pembelajaran Jarak Jauh (elearning) (Tabel 2).

Pembelajaran daring merupakan sistem pembelajaran yang dilakukan dengan tidak bertatap muka langsung, tetapi menggunakan platform yang dapat membantu proses belajar mengajar yang dilakukan meskipun jarak jauh. Tujuan dari adanya pembelajaran daring ialah memberikan layanan pembelajaran bermutu dalam jaringan yang bersifat masif dan terbuka untuk menjangkau peminat ruang belajar agar lebih banyak dan lebih luas.

Tabel 1. Jumlah Sekolah yang menyelenggarakan E-learning tingkat SD, SMP, SMA, dan SMK untuk tiap Kecamatan di Kabupaten Majene pada tahun 2021

\begin{tabular}{llcccc}
\hline No. & Subdistrict & SD & SMP & SMA & SMK \\
\hline $\mathbf{1}$ & Pamboang & 30 & 11 & 2 & 1 \\
\hline $\mathbf{2}$ & Ulumanda & 20 & 7 & 1 & 2 \\
\hline $\mathbf{3}$ & Tammerodo Sendana & 15 & 5 & 1 & 1 \\
\hline $\mathbf{4}$ & Tubo Sendana & 10 & 3 & 1 & 1 \\
\hline $\mathbf{5}$ & Banggae & 35 & 6 & 2 & 2 \\
\hline $\mathbf{6}$ & Sendana & 27 & 11 & 4 & 4 \\
\hline $\mathbf{7}$ & Malunda & 22 & 7 & 2 & 3 \\
\hline $\mathbf{8}$ & Banggae Timur & 32 & 12 & 9 & 3 \\
\hline Total & $\mathbf{1 9 1}$ & $\mathbf{6 2}$ & $\mathbf{2 2}$ & $\mathbf{1 7}$ \\
\hline
\end{tabular}

Tabel 2. Jumlah Siswa yang Mengikuti E-learning untuk SD, SMP, SMA, dan SMK di Kabupaten Majene Tahun 2021

\begin{tabular}{ll}
\hline Tingkat Pendidikan & Jumlah Siswa \\
\hline SD & 22,889 \\
\hline SMP & 11,299 \\
\hline SMA & 5,397 \\
\hline SMK & 5,364 \\
\hline Total & 44,949 \\
\hline
\end{tabular}

Proses pembelajaran daring pada tingkatan Sekolah Dasar, dibutuhkan pendampingan dari orang yang lebih dewasa, terutama orang tua. Hal ini sebagai upaya agar proses pembelajaran dapat berjalan sesuai dengan tujuan pembelajaran yang telah ditetapkan sebelumnya. Keberhasilan proses pembelajaran juga dipengaruhi oleh orang yang mendampingi siswa saat pembelajaran berlangsung. Di Kabupaten Majene, Persentase banyaknya orang yang mendampingi siswa saat proses pembelajaran berlangsung dilakukan oleh orang tua, saudara, keluarga lain (paman, tante atau sepupu), dan tetangga terdekat (termasuk guru privat). Dari 2.865 (65,41\%) responden untuk sekolah dasar, nampak bahwa sebanyak $56,79 \%$ didampingi oleh Orang Tua, dan 16,96\% dilakukan oleh tetangga. Kemudian 
pada tingkat SMP dengan 930 (21,23\%) responden mengungkapkan bahwa siswa didampingi oleh orang tua sebesar $42,90 \%$, tetangga termasuk guru privat sebanyak 28,92\%.(Tabel 3).

\section{Tabel 3. Pendamping siswa Selama Pelaksanaan Elearning Di Kabupaten Majene} (\%)

\begin{tabular}{lllll}
\hline \multirow{2}{*}{ Level of Education } & \multicolumn{4}{l}{ Pendamping PJJ (\%) } \\
\cline { 2 - 5 } & $\begin{array}{l}\text { Orang } \\
\text { Tua }\end{array}$ & $\begin{array}{c}\text { Saudara } \\
\text { kandung }\end{array}$ & $\begin{array}{l}\text { Keluarga } \\
\text { Lain }\end{array}$ & $\begin{array}{l}\text { Tetangga/Guru } \\
\text { Privat }\end{array}$ \\
\hline Primary school & 56.79 & 14.90 & 11.34 & 16.96 \\
\hline Junior high school & 42.90 & 11.08 & 17.10 & 28.92 \\
\hline Senior High School & 36.67 & 8.18 & 20.91 & 34.24 \\
\hline Vocational high School & 33.73 & 6.67 & 23.92 & 35.69 \\
\hline
\end{tabular}

Dari sekian banyak cara dalam melaksanakan pembelajaran secara jarak jauh, salah satu cara penerapan Pembelajaran Daring adalah dilakukan secara Komunikasi Video Streaming, yaitu sebuah cara komunikasi melalui fasilitas teknologi internet dengan melakukan pertemuan tidak langsung yang secara virtual berinteraksi menggunakan applikasi flatform video teleconference yang dapat digunakan untuk peserta yang lebih dari dua orang secara realtime atau dalam satu waktu yang serempak. Aplikasi video teleconference antara lain adalah; Google Meet, Microsoft Team, Cisco Webex, Skype dan Zoom. Teknologi Video Content, Video Teleconference mau pun Video Call Streaming sebagai sebagai salah satu fasilitas dalam melaksanakan Pembelajaran Jarak Jauh dengan Komunikasi Virtual yang mampu berinteraksi secara tidak langsung antara Guru dan Siswa menjadi sangat dibutuhkan dan bermanfaat dalam bidang pendidikan dan komunikasi, tidak hanya dalam masa isolasi dari pandemi wabah COVID-19, tetapi juga dalam beberapa masa ke depan yang tidak membutuhkan keberadaan orang pada satu tempat di waktu yang sama untuk berinteraksi.

Ada beberapa aplikasi juga dapat membantu kegiatan belajar mengajar, misalnya WhatsApp, Google Form, Google Classroom, Google Drive, Youtube, WA grup, Tuweb, aplikasi Zoom Meeting, web blog, edmodo dan lain-lain. Pemerintah juga mengambil peran dalam menangani ketimpangan kegiatan belajar selama pandemi covid 19 ini.

Platform Aplikasi resmi Kemendikbud RI, ada 12 aplikasi yang bisa diakses pelajar untuk belajar di rumah yaitu (1) Rumah belajar; (2) Meja kita; (3) Icando; (4) Indonesiax; (5) Google for education; (6) Kelas pintar; (7) Microsoft office 365; (8) Quipper school (9) Ruang guru; (10) Sekolahmu; (11) Zenius; (12) Cisco webex. Tantangan dari adanya pembelajaran daring salah satunya adalah keahlian dalam penggunaan teknologi dari pihak pendidik maupun peserta didik.

Aplikasi-aplikasi pembelajaran jarak jauh yang umumnya digunakan oleh guru dan siswa di Kabupaten Majene, sangat beragam, sesuai kesepakatan antara orang tua, murid, guru, dan pemeritah daerah. Dari penuturan responden, nampak bahwa 
aplikasi yang sering digunakan adalah WhatsApp, Ruang Guru, Zoom Meeting, dan Google Calssroom, dan aplikasi-aplikasi lain (Tabel 4). Hal tersebut diperkuat dengan hasil wawancara mendalam;

"anak kami yang di kelas 5 Sekolah Dasar, menggunakan WhatsApp Grup untuk memperoleh materi-materi pembelajaran, dan kadang-kadang menggunakan Zoom Meeting ketika ada yang mau dijelaskan oleh guru mereka" (Orang Tua Siswa, Wanita, 36 Tahun, Kecamatan Banggae).

"Hampir setiap hari, menerima materi dari guru-guru melalui WhatsApp Grup, ada dalam bentuk video penjelasan, ada modul, ada power point, dan info-info terkait materi pembelajaran" (Orang Tua siswa, laki-laki 28 tahun, kecamatan Pamboang).

"Saya lebih suka WhatsApp Grup, lebih mudah dilihat, dan tidak perlu buka aplikasi-aplikasi rumit" (Keluarga siswa, Wanita, 47 tahun, Kecamatan Malunda)

Tabel 4. Persentase Penggunaan Aplikasi E-Learning Per Minggu Siswa Sekolah Dasar

\begin{tabular}{ll}
\hline Aplikasi PJJ & Percentage \\
\hline WhatsApps & 64.76 \\
\hline Aplikasi dari Pemerintah & 20.07 \\
\hline Zoom & 10.11 \\
\hline Aplikasi Lain & 5.05 \\
\hline
\end{tabular}

\section{Distorsi Pendidikan Karakter siswa di Masa Pandemi Covid-19}

Karakter membedakan manusia dengan makhluk hidup lainnya. la merupakan kepribadian atau ciri yang mencirikan seseorang yang didapatkan melalui proses pembentukan dalam lingkungan hidupnya.

Karakter bisa dibentuk dan dikondisikan oleh guru di sekolah atau para orang tua di rumah serta lingkungan masyarakat. Guru dan orang tua harus menyediakan atau mengkondisikan wadah yang baik sebagai tempat membangun nilai-nilai karakter yang mencirikan dan memiliki perilaku moral yang baik.

Pemerintah telah mengeluarkan Peraturan Presiden Nomor 87 tahun 2017 tentang penguatan Pendidikan Karakter. Tujuan dari Peraturan Presiden ini adalah membentuk pribadi bangsa yang berbudaya melalui penguatan nilai-nilai karakter yang digali dari budaya bangsa sendiri.

Penguatan Pendidikan Karakter merupakan upaya pemerintah di bawah satuan pendidikan untuk memeperkuat karakter peserta dididk melalui harmonisasi olah hati, olah pikir, olah raga, melibatkan tiga satuan pendidikan yaitu sekolah, keluarga dan masyarakat. Kemudian ditindaklanjuti dengan Permendikbud Nomor 20 Tahun 2018 tentang Penguatan Pendidikan Karakter, memperkuat pendidikan karakter yaitu dengan melaksanakan pendidikan karakter yang berdasar asas Pancasila dengan menanamkan sikap religious, jujur, toleran, disiplin, bekerja keras, kreatif, mandiri, demokratis, rasa ingin tahu, semangat kebangsaan, cinta tanah air, menghargai prestasi, komunikatif, cinta damai, gemar membaca, peduli lingkungan, peduli sosial, 
dan bertanggung jawab. Semua sikap tersebut merupakan penjabaran dari 5 (lima) nilai pokok yaitu religiusitas, nasionalisme, kemandirian, gotong royong, dan integritas.

Pendidikan karakter merupakan pendidikan yang berkaitan dengan kualitas instrinsik individu seutuhnya, baik kepribadian, watak, temperamen, bakat, interaksi manusia dengan Tuhan, interaksi manusia dengan sesama, dan interaksi manusia dengan lingkungan sekitar.

Di sekolah, penguatan pendidikan karakter telah dilakukan dengan baik yaitu dengan menyelipkan nilai-nilai karakter ini pada setiap aktivitas pembelajaran. Namun hal ini tidak akan berjalan maksimal karena semestinya pendidikan karakter harus melibatkan semua aspek lingkungan secara garis besar yaitu sekolah, keluarga, dan masyarakat. Di masyarakat pola pendidikan karakter ini sebenarnya telah dilakukan melalui aturan norma serta kearifan lokal yang berlaku di masyarakat, sehingga setiap individu akan dibatasi dan dilurskan oleh aturan norma serta kearifan lokal tersebut sehingga menjadi terbiasa dalam sikap karakter yang sesuai dan diterima di masyarakat itu sendiri. Sedangkan pendidikan karakter di lingkungan keluarga merupakan pendidikan karakter terbaik yang bisa dilakukan. Namun, selama ini usaha optimalisasi pendidikan karakter di lingkungan keluarga ini belum maksimal atau belum dikonsep dengan baik. Karena kurangnya kesadaran orang tua dalam pendidikan karakter untuk anaknya, kesibukan orang tua, dan ketidaktahuan orang tua bagaimana cara membentuk karakter anak yang baik.

Serangan Covid-19 yang memaksa pelaksanaan pembelajaran jarak jauh dari rumah ini, tidak hanya mengancam aspek kesehatan fisik, namun juga menjadi ancaman pada pengembangan nilai-nilai karakter yang hendak dibangun pada siswa. Karena itu, Penelitian ini menggambarkan distorsi pendidikan karakter siswa selama pembelajaran jarak jauh dari rumah di era pandemi Covid-19.

\section{Distorsi pada Karakter Nilai Religius}

Nilai karakter religius memiliki tiga indikator utama, yaitu: hubungan individu dengan Tuhan, individu dengan sesama, dan individu dengan alam semesta atau lingkungan.

Dalam membangun karakter religius atau penanaman nilai-nilai keagamaan pada siswa selama pembelajaran jarak jauh yang paling mengkuatirkan adalah distorsi pada hubungan dengan sesama. Nilai ini hampir tidak menjadi perhatian dalam proses belajar mengajar selama menggunakan aplilkasi-aplikasi e-learning.

Nilai karakter religius yang mengalami ancaman distorsi mengkuatirkan adalah pada aspek kepedualian pada sesama, yaitu di bawah 15\% untuk semua tingkatan pendidikan (Tabel 5). Ancaman distorsi kepedulian pada sesama ini makin serius di tingkat sekolah dasar yang hanya mencapai, 7,99\%. Hal ini dapat menimbulkan intoleransi, sifat individualistik, dan kurangnya penghargaan kepada orang lain. Kemudian karakter untuk nilai kepedulian pada lingkungan juga termasuk mengkuatirkan yang rata-rata di bawah $25 \%$ (Tabel 5). Hal ini dapat menimbulkan 
ketidak pedulian pada keberlanjutan lingkungan dan munculnya tindakan-tindakan perusak lingkungan sekitar.

Tabel 5. Pengembangan karakter religius (beribadah, peduli sesama, dan peduli lingkungan) dalam pembelajaran jarak jauh pada siswa di Kabupaten Majene (\%)

\begin{tabular}{llll}
\hline \multirow{2}{*}{ Level of Education } & \multicolumn{3}{l}{ Unsur Karakter Religius (\%) } \\
\cline { 2 - 4 } & $\begin{array}{l}\text { Taat } \\
\text { Beribadah }\end{array}$ & $\begin{array}{l}\text { Kepedulian pada } \\
\text { Orang Lain }\end{array}$ & $\begin{array}{l}\text { Kepedulian pada } \\
\text { Lingkungan }\end{array}$ \\
\hline SD & 71.59 & 7.99 & 20.42 \\
\hline SMP & 64.19 & 13.01 & 22.80 \\
\hline SMA & 67.27 & 8.79 & 23.94 \\
\hline SMK & 68.63 & 14.51 & 16.86 \\
\hline
\end{tabular}

\section{Distorsi pada Karakter Nilai Nasionalis}

Karakter nasionalisme pada dasarnya harus tertanam di benak peserta didik, karena peserta didik tersebut akan menjadi pemimpin bangsa di masa depan. Nilai karakter nasionalis merupakan cara berpikir, bersikap, dan berbuat yang menunjukan kesetiaan, kepedulian, dan penghargaan yang tinggi terhadap bahasa, lingkungan fisik, sosial, budaya, ekonomi, dan politik bangsa, menempatkan kepentingan bangsa dan negara di atas kepentingan diri dan kelompoknya.

Penelitian ini menggunkan 5 (lima) komponen yang membangun karakter nasionalisme, yaitu 1) komponen cinta tanah air; 2) komponen menghormati keragaman budaya, 3) Komponen apresiasi budaya bangsa, 4) komponen taat hukum, dan 5) komponen unggul dan berprestasi (Saputra, dkk, 2019).

Komponen cinta tanah air, meliputi; rela berkorban, cinta tanah air, menjaga lingkungan, taat hukum, dan disiplin. Komponen menghormati keragaman budaya, meliputi; unggul dan menghormati keragaman budaya, suku, dan agama. Komponen apresiasi budaya bangsa, meliputi; apresiasi budaya bangsa dan menjaga kekayaan budaya bangsa. Komponen taat hukum, meliputi; rela berkorban, taat hukum, dan disiplin. Komponen unggul dan berprestasi, meliputi; menjaga kekayaan budaya bangsa serta unggul dan berprestasi.

Ancaman distorsi nilai karakter nasionalisme pada siswa selama pembelajaran jarak jauh era pandemi Covid-19 dapat diukur melalui perilaku nasionalis yang tereduksi, yaitu pada komponen cinta tanah air, nampak bahwa para siswa hampir tidak pernah lagi menghadiri upacara bendera secara rutin, baik peringatan hari pahlawan, proklamasi kemerdekaan maupun peringatan hari-hari nasional lainnya (Tabel 6). Hal ini menjadi ancaman makin rendahnya karakter kebangsaan pada diri siswa. Merayakan hari-hari besar nasional bertujuan untuk mengenang dan menghormati apa yang telah terjadi pada hari-hari besar. Perayaan ini sebagai sarana penanaman nilai-nilai nasionalisme cinta tanah air. 
SEMINAR NASIONAL HASIL PENELITIAN 2021

"Penguatan Riset, Inovasi, dan Kreativitas Peneliti di Era Pandemi Covid-19"

ISBN: 978-623-387-014-6

\section{Table 6. Persentase Keaktifan siswa dalam perayaan nasional selama Pembelajaran jarak jauh}

\begin{tabular}{lll}
\hline \multirow{2}{*}{ Level of Education } & \multicolumn{2}{l}{$\begin{array}{l}\text { Keaktifan dalam Perayaan Nasional } \\
(\%)\end{array}$} \\
\cline { 2 - 3 } & Tdk Aktif & Active \\
\hline SD & 96.96 & 3.04 \\
\hline SMP & 90.86 & 9.14 \\
\hline SMA & 88.18 & 11.82 \\
\hline SMK & 85.88 & 14.12 \\
\hline
\end{tabular}

Dirtorsi lain pada karakter nasionalisme akibat Pendidikan Jarak Jauh adalah munculnya penyeragaman kemampuan siswa, baik dari aspek ekonomi maupun tingkat pengetahuan. E-learning memaksa siswa untuk memiliki smartphone atau laptop, yang harganya belum terjangkau oleh kemampuan keluarganya. Selain itu, penggunaan kuota dan jaringan internet yang belum merata, yang sebagian siswa harus mencari wilayah-wilayah yang jauh dari tempat tinggal mereka untuk memungkinkan dapat belajar secara daring.

Distorsi karakter nasionalisme ini menjadi ancaman serius pada pendidikan karakter multikultural yang memberikan penekanan terhadap proses penanaman cara hidup yang saling menghormati, tulus, dan toleran terhadap keanekaragaman budaya hidup di tengah-tengah masyarakat dengan tingkat pluralitas yang tinggi.

Pendidikan multikultural merupakan sebuah wacana yang lintas batas karena terkait dengan masalah-masalah keadilan sosial, demokrasi, dan hak asasi manusia. Pendidikan multikultural adalah pendidikan yang memperhatikan secara sungguhsungguh latar belakang dari aspek keragaman suku, etnis, ras, agama, dan budaya. Oleh karena itu, pengembangan karakter nilai multikultural adalah pendidikan mengenai keragaman budaya yang bertujuan untuk menanamkan sikap bertoleransi terhadap perbedaan-perbedaan yang ada.

Pendidikan karakter multikulral adalah menanamkan nilai-nilai pluralisme, humanisme, dan demokrasi secara langsung oleh masyarakat sejak usia dini di sekolah yang bertujuan mengajak siswa untuk bisa menerima perbedaan yang ada sebagai proses yang alamiah.

\section{Distorsi pada Karakter Kemandirian}

Kemandirian memiliki ciri-ciri, yaitu: (1) percaya diri, (2) mampu bekerja sendiri, (3) menguasai keahlian dan keterampilan yang sesuai dengan kerjanya, (4) menghargai waktu, (5) bertanggung jawab.

Nilai karakter kemandirian harus dikembangkan sekolah guna membentuk generasi muda yang mandiri. Peserta didik yang mandiri diharapkan mampu 1) lebih percaya diri dalam bertindak, 2) mempertimbangkan pendapat dan nasihat dari orang lain, 3) memiliki kemampuan mengambil keputusan, dan 4) tidak mudah terpengaruh oleh orang lain. 
Distorsi karakter nilai kemandirian siswa selama pembelajaran jarak jauh adalah berkembangnya sikap maupun perilaku peserta didik yang mengantungkan diri pada orang tua atau pendampingnya selama melakukan pembelajaran daring.

Hal ini dipicu dalam aktifitas proses pembelajaran online, guru selalu memberikan tugas yang tidak sedikit bahkan bukan hanya satu guru saja tetapi semua guru mata pelajaran yang mengakibatkan tugas menumpuk dalam waktu sehari dan anak akhirnya menjadi kelelahan dan akhirnya bosan. Hal itu menyebabkan siswa tidak mau mengerjakan tugas dan pengerjaannya diselesaikan oleh orang tuanya, kakaknya atau orang lain, tentu akan menimbulkan dampak, yaitu siswa mengalami ketergantungan pada bantuan orang lain, kurang mandiri dalam menyelesaikan tugas, dan cenderung menjadi anak yang kurang percaya diri (Tabel 8).

Tabel 8. Persentase Proses Penyelesaian Pekerjaan Rumah Siswa Selama Pendidikan jarak Jauh

\begin{tabular}{|c|c|c|c|c|}
\hline \multirow[b]{2}{*}{ Level of Education } & \multicolumn{4}{|c|}{ Pekerjaan Rumah (\%) } \\
\hline & Tanpa & Bantuan & Dengan & Bantuan \\
\hline SD & 54.03 & & 45.97 & \\
\hline SMP & 62.90 & & 37.10 & \\
\hline SMA & 71.21 & & 28.79 & \\
\hline SMK & 69.41 & & 30.59 & \\
\hline
\end{tabular}

Distorsi karakter kemandirian siswa akan semakin parah ketika pembelajaran jarak jauh memberi tekanan berat dan berpotensi menjadi lebih kuat manakala tidak ada bimbingan atau pengawasan ketika belajar di rumah masing-masing. Mereka kehilangan "mitra curhat" (confidant partner) antar-teman sebaya.

Lebih dari itu, mekanisme belajar dari rumah telah mengubah pula jadwal kegiatan dari para orangtua murid yang harus turut mengawasi anak-anaknya dalam mengikuti program pelajaran di rumah. Tidak cukup hanya mempersiapkan anak-anak untuk bangun pagi dan persiapan mengikuti pelajaran sekolah, akan tetapi juga turut serta dalam proses membimbing dalam mengikuti tata cara pelajaran "online" dalam memandu anak mengikuti pelajarannya

Nilai karakter mandiri merupakan sikap dan perilaku tidak bergantung pada orang lain dan mempergunakan segala tenaga, pikiran, dan waktu untuk merealisasikan harapan, mimpi, dan cita-cita. Unsur nilai kemandirian, antara lain, etos kerja atau kerja keras, tangguh dan tahan banting, daya juang, profesional, kreatif, keberanian, dan menjadi pembelajar sepanjang hayat.

\section{Distorsi pada Karakter Kegotong-royongan}

Karakter gotong-royong mencerminkan tindakan menghargai semangat kerja sama dan bahu membahu menyelesaikan persoalan bersama, menjalin komunikasi dan persabatan, serta memberi bantuan atau pertolongan pada orang-orang yang membutuhkan. Sub-nilai gotong-royong, antara lain, menghargai, kerja sama, inklusif, 
komitmen atas keputusan bersama, musyawarah dan mufakat, tolong-menolong, solidaritas, empati, anti diskriminasi, anti kekerasan, dan sikap kerelawanan.

Kegiatan belajar merupakan proses interaksi dalam kelas untuk membangun konsep pemahaman siswa. Proses interaksi antar siswa sangat penting, namun pada pembelajaran jarak jauh tanpa disadari terjadi kekurangan interaksi antar siswa sehingga memunculkan sikap individualis siswa.

Distorsi pada karakter gotong royong dipicu oleh kurangnya interaksi siswa dalam pembelajaran jarak jauh, dan pemanfaatan media aplikasi e-lerning yang tidak sesuai dengan pengembangan karakter siswa. Hal ini menjadi pemicu lahirnya nilai individualis dalam diri siswa.

Interaksi yang kurang antar siswa mengakibakan kurangnnya saling pemahaman dan akhirnya tidak saling menghargai, kerja sama antar siswa menjadi berkurang, siswa menjadi sangat tertutup dengan teman sebaya, tidak terbangun komitmen dan keputusan bersama, serta tidak terbangunnya karakter musyawarah dan mufakat.

Individualis yang muncul dalam diri siswa mengibatkan kurangnya tolongmenolong antar siswa, solidaritas menjadi berkurang, rasa empati terhadap sesama juga tergerus yang mengakibatkan sikap kerelawanan menjadi rendah.

\section{Distorsi pada karakter Integritas}

Nilai karakter integritas merupakan nilai yang mendasari perilaku yang didasarkan pada upaya menjadikan dirinya sebagai orang yang selalu dapat dipercaya dalam perkataan, tindakan, dan pekerjaan, serta memiliki komitmen dan kesetiaan pada nilai-nilai kemanusiaan dan moral atau integritas moral. Karakter integritas meliputi sikap tanggung jawab sebagai warga negara, aktif terlibat dalam kehidupan sosial, serta konsistensi dalam tindakan dan perkataan yang berdasarkan kebenaran. Sub-nilai integritas, antara lain, kejujuran, cinta pada kebenaran, setia, komitmen moral, anti korupsi, keadilan, tanggung jawab, keteladanan, dan menghargai martabat individu.

Distorsi karakter Integritas siswa pada pembelajaran jarak jauh, yaitu maraknya kecenderungan siswa untuk tidak jujur pada saat mengikuti tes/ujian seperti; ulangan harian, ujian mid semester, ujian akhir semester dan lain sebagainya. Bentuk kecurangan siswa yaitu dengan memanfaatkan mesin pencari (misalnya; google search) untuk mencari jawaban, serta menggunakan chating di media sosial antar teman.

Perilaku menyontek merupakan salah satu masalah yang masih dialami oleh dunia pendidikan dan akan terus menjadi perhatian lembaga pendidikan kedepannya. Perilaku menyontek merupakan perbuatan tidak jujur, curang dan dilakukan secara ilegal untuk memalsukan hasil belajar atau untuk mendapatkan jawaban pada saat ujian atau tes. Kecenderungan perilaku menyontek yang dilakukan oleh siswa karena siswa ingin menghindari kegagalan dari nilai akademis dengan cara yang tidak jujur.

Dalam dunia pendidikan atau sekolah beberapa perbuatan yang termasuk 
dalam kategori menyontek antara lain yaitu meniru pekerjaan teman, bertanya langsung kepada teman ketika sedang mengerjakan tes ujian, membawa catatan pada kertas, pada anggota badan atau pada pakaian masuk ruang ujian, menerima droping jawaban dari pihak luar, mencari bocoran soal, arisan (saling tukar) mengerjakan tugas dengan teman, menyuruh atau meminta bantuan orang lain dalam menyelesaikan tugas ujian di kelas atau tugas. Beberapa alasan yang dikemukakan siswa, tentang apa yang mendorong mereka ingin menyontek, diantaranya adalah : 1 . Solidaritas antar teman. 2. Hampir semua teman menyontek. 3. Tidak siap mengikuti ujian/tes (tidak bisa menjawab). 4. Tidak percaya diri dengan jawaban sendiri. 5. Malu jika nilainya kecil. 6. Ada kesempatan untuk menyontek. Ini adalah beberapa alasan mengapa siswa melakukan kecurangan/menyontek ketika mereka mengikuti tes/ujian. Secara umum mereka menyontek atau berkerjasama dalam mengerjakan tes, merupakan bentuk solidaritas antar teman dan hampir semua teman dalam kelas melakukannya. Adapun sumber contekan berasal dari siswa yang dianggap pintar atau mampu secara akademik. Berdasarkan alasan-alasan yang dikemukakan siswa hal ini menunjukkan bahwa budaya menyontek sudah menjadi kebiasaan yang berlangsung sejak lama.

\section{KESIMPULAN}

Pelaksanaan pembelajaran jarak jauh selama pandemi Covid-19 di Kabupaten Majene, Propinsi Sulawesi Barat, Indonesia dilakukun secara daring (e-learning) yang diikuti sebanyak 292 sekolah, mulai dari Sekalh dasar, sekolah Menengah Pertama, sekolah menegah Atas, dan Sekolah Menengah Kejuruan yang tersebar pada 8 (delapan) Kecamatan dengan jumlah 44.949 peserta didik yang aktif melaksanakan Pembelajaran Jarak Jauh (e-learning). Aplikasi yang sering digunakan selama pembelajaran jarak jauh adalah WhatsApp, Ruang Guru, Zoom Meeting, dan Google Calssroom, dan aplikasi-aplikasi lain.

Serangan Covid-19 yang memaksa pelaksanaan pembelajaran jarak jauh dari rumah ini, tidak hanya mengancam aspek kesehatan fisik, namun juga menjadi ancaman pada pengembangan nilai-nilai karakter yang hendak dibangun pada siswa. Distorsi yang terjadi pada karakter siswa selama pembelajaran jarak jauh dari rumah di era pandemi Covid-19, yaitu:

Pertama, distorsi karakter religius terjadi pada aspek kepedualian pada sesama yang dapat menimbulkan intoleransi, individualistik, dan kurangnya penghargaan kepada orang lain. Selain itu, distorsi juga terjadi pada kepedulian lingkungan yang dapat menimbulkan tindakan-tindakan perusak lingkungan sekitar.

Kedua, distorsi pada karakter nasionalisme muncul karena selama pembelajaran jarak jauh para siswa hampir tidak pernah lagi menghadiri kegiatan bersifat kenegaraan.

Ketiga, distorsi karakter kemandirian siswa ditandai dengan berkembangnya sikap yang mengantungkan diri pada orang tua atau pendampingnya selama melakukan pembelajaran daring. 
Keempat, distorsi pada karakter gotong royong dipicu oleh kurangnya interaksi antar siswa mengakibakan kurangnnya saling pemahaman, tidak saling menghargai, siswa menjadi sangat tertutup dengan teman sebaya. Individualis yang muncul dalam diri siswa mengibatkan kurangnya tolong-menolong antar siswa, kurangnya solidaritas, rendahnya rasa empati yang mengakibatkan sikap kerelawanan menjadi rendah.

Kelima, Distorsi karakter Integritas siswa yaitu kecenderungan siswa untuk tidak jujur pada saat mengikuti tes/ujian. Bentuk kecurangan siswa yaitu dengan memanfaatkan mesin aplikasi pencari untuk menemukan jawaban, serta menggunakan chating di media sosial antar teman.

\section{UCAPAN TERIMA KASIH}

Terima kasih kepada Civitas Akademika, Departemen Sosiologi Program Doktor Pascasarja Universitas Negeri Makassar (UNM) yang telah memberi arahan dan motivasi yang luar biasa yang diberikan kepada penulis. Kemudian kepada Pemerintah Daerah Kabupaten Majene yang telah memberi fasilitasi dan bantuan yang sangat berharga, terima kasih.

\section{DAFTAR PUSTAKA}

Agustang, A. (2011). Pendekatan Penelitian Kualitatif dan Kuantitatif Suatu Tinjauan Kritis. In Makassar: Andira Publisher. Andira Publisher.

Andi Agustang. (2015). Dasar-Dasar Filsafat Penelitian Untuk Pengembangan Ilmu (I. I. Idrus (ed.); pertama). CV Multi Global.

Agustang, A., Mutiara, I. A., \& Asrifan, A. (2021, January 10). Masalah Pendidikan di Indonesia. https://doi.org/10.31219/osf.io/9xs4h

Agustang, A., A, A. D. M. P., \& Asrifan, A. (2021, January 20). PERAN PENDIDIKAN DALAM MEMBANGUN KARAKTER BANGSA https://doi.org/10.31219/osf.io/na9pu

Agustang, A. Y. A., Herman, H., Said, M., \& Agustang, A. (2021). Upaya Guru IPS Dalam Meningkatkan Motivasi Belajar Siswa Pada Masa Covid 19 Di SMP. Phinisi Integration Review, 4(1), 144-149.

Ahmad, I. F. (2020). Asesmen Alternatif Dalam Pembelajaran Jarak Jauh Pada Masa Darurat Penyebaran Coronavirus Disease (Covid-19) Di Indonesia. PEDAGOGIK: Jurnal Pendidikan, 7(1), 195-222. https://doi.org/10.33650/pjp.v7i1.1136

Al Lily, A. E., Ismail, A. F., Abunasser, F. M., \& Alhajhoj Alqahtani, R. H. (2020). Distance education as a response to pandemics: Coronavirus and Arab culture. $\begin{array}{llll}\text { Technology in } & \text { Society, }\end{array}$ https://doi.org/10.1016/j.techsoc.2020.101317

Argaheni, N. B. (2020). Sistematik Review: Dampak Perkuliahan Daring Saat Pandemi COVID-19 TerhadapMahasiswalndonesia. PLACENTUM: Jurnal 
IlmiahKesehatan Dan Aplikasinya, 8(2), 99. https://doi.org/10.20961/placentum.v8i2.43008

Ariadhy, \& Shulby Yozar, D. (2020). Permasalahan Pembelajaran Jarak Jauh Di Era Pandemi. ANOA Jurnal Pengabdian Kepada Masyarakat, 3(1), 13-18. https://doi.org/http://dx.doi.org/10.1234/anoa.v1i3 13640.g9544

Azhari, B., \& Fajri, I. (2021). Distance learning during the COVID-19 pandemic: School closure in Indonesia. International Journal of Mathematical Education in Science and Technology, 1-21. https://doi.org/10.1080/0020739X.2021.1875072

Bokayev, B., Torebekova, Z., Davletbayeva, Z., \& Zhakypova, F. (2021). Distance learning in Kazakhstan: estimating parents' satisfaction of educational quality during the coronavirus. Technology, Pedagogy and Education, 00(00), 1-13. https://doi.org/10.1080/1475939X.2020.1865192

Daming, M., Agustang, A., Idkhan, A. M., \& Rifdan, R. (2021). IMPLEMENTASI KEBIJAKAN MAKASSAR RECOVER DALAM PENANGANAN COVID-19 DI KOTA MAKASSAR. JISIP (Jurnal Ilmu Sosial Dan Pendidikan), 5(4).

Eko, B. S., \& Putranto, H. (2019). The Role of Intercultural Competence and Local Wisdom in Building Intercultural and Inter-religious Tolerance. Journal of Intercultural Communication Research, 48(4), 341-369. https://doi.org/10.1080/17475759.2019.1639535

Ernita Dewi. (2012). Transformasi Sosial Dan Nilai Agama. Jurnal Imlu-IImu Usuluddin Dan Filsafat, 128, 112-121.

Ferraro, F. V., Ambra, F. I., Aruta, L., \& lavarone, M. L. (2020). Distance learning in the covid-19 era: Perceptions in Southern Italy. Education Sciences, 10(12), 1-10. https://doi.org/10.3390/educsci10120355

Gardanova, Z., Ponkratov, V., Kuznetsov, N., Nikitina, N., Dudnik, O., Latypova, E., \& Shcherbatykh, S. (2020). A model for optimizing the structure of teaching techniques for distance learning in the russian higher education system. Journal of Open Innovation: Technology, Market, and Complexity, 6(4), 1-21. https://doi.org/10.3390/joitmc6040147

Guntoro. (2020). Transformasi Budaya Terhadap Perubahan Sosial Di Era Globalisasi. Jurnal Asketik: Agama Dan Perubahan Sosial, 4(1), 22-33.

Jusuf, H., Sobari, A., \& Fathoni, M. (2020). Pengaruh Pembelajaran Jarak Jauh Bagi Siswa SMA Di Era Covid-19. Jurnal Kajian Ilmiah, 1(1), 15-24. https://doi.org/10.31599/jki.v1i1.212

Kamar, K., Asbari, M., Purwanto, A., Nurhayati, W., \& Sudiyono, R. N. (2020). Membangun Karakter Siswa Sekolah Dasar Melalui Praktek Pola Asuh Orang Tua Berdasarkan Genetic Personality. JINoP (Jurnal Inovasi Pembelajaran), 6(c), 75-86. https://doi.org/https://doi.org/10.22219/jinop.v6i1.10196

Komara, E. (2018). Penguatan Pendidikan Karakter dan Pembelajaran Abad 21. SIPATAHOENAN: South-East Asian Journal for Youth, Sports \& Health Education, 4(1), 17-26. www.journals.mindamas.com/index.php/sipatahoenan Leasa, M., \& Batlolona, J. R. (2017). Full Day School Dalam Pembentukan Karakter Siswa 
Smkn 13 Kota Malang. Jurnal Ilmu Sosial Dan Humaniora, 6(1), 73. https://doi.org/10.23887/jish-undiksha.v6i1.9903

Maharani; Hasyim, M. q. S. (2018). Sibaliparriq Culture Dynamics in Mandar Community. Proceeding of ICER 124th International Conference, 6, p28-32.

Marini, S., \& Milawati, M. (2020). Distance Learning Innovation Strategy in Indonesia During the COVID-19 Pandemic. 488(Aisteel), 416-421. https://doi.org/10.2991/assehr.k.201124.085

Megawanti, P., Megawati, E., \& Nurkhafifah, S. (2020). Persepsi Peserta Didik terhadapPJJ pada Masa Pandemi COVID-19. Jurnal IImiah Pendidikan, 7(2), 7582.

Pujiasih, E. (2020). Membangun Generasi Emas Dengan Variasi Pembelajaran Online Di Masa Pandemi Covid-19. Ideguru: Jurnal Karya IImiah Guru, 5(1), 42-48. https://doi.org/10.51169/ideguru.v5i1.136

Ramlafatma, R., Oruh, S., \& Agustang, A. (2021). Efektivitas Pendidikan Moral Dalam Pembentukan Karakter Siswa Di TK Islam Terpadu Asa Sumbawa. Jurnal Ilmiah Mandala Education, 7(4).

Sadikin, A., \& Hamidah, A. (2020). Pembelajaran Daring di Tengah Wabah Covid-19. Biodik, 6(2), 109-119. https://doi.org/10.22437/bio.v6i2.9759

Sibarani, R. (2018). The role of local wisdom in developing friendly city. IOP Conference Series: Earth and Environmental Science, 126(1). https://doi.org/10.1088/1755- 1315/126/1/012094

Trisnawati, W., \& Sugito, S. (2020). Pendidikan Anak dalam Keluarga Era Covid-19. Jurnal Obsesi : Jurnal Pendidikan Anak Usia Dini, 5(1), 823-831. https://doi.org/10.31004/obsesi.v5i1.710

Wahyono, P., Husamah, H., \& Budi, A. S. (2020). Guru profesional di masa pandemi COVID-19: Review implementasi, tantangan, dan solusi pembelajaran daring. Jurnal Pendidikan Profesi Guru, 1(1), 51-65. http://ejournal.umm.ac.id/index.php/jppg/article/view/12462 